\title{
Communication Pattern of Family Planning Field Officers in Increasing Community Participation of Long-Term Contraception Usage
}

\author{
Nuraisyah Ambo ${ }^{1}$, Andi Febri Herawati ${ }^{2}$ \\ nuraisyahambo@gmail.com \\ ${ }^{1}$ Department of Sociology, Faculty of Social and Political Sciences, Tadulako University, \\ Palu, Indonesia \\ ${ }^{2}$ Department of Communication Sciences, Faculty of Social and Political Sciences, Tadulako \\ University, Palu, Indonesia
}

Received: January 5, 2021

Received in Revised: January 27, 2021

Accepted: February 8, 2021

\begin{abstract}
The Field Officers play a role to convey family planning information and services. Thus, the community members can receive and understand family planning information properly and giving feedback. The problem posed is on how the role of Family Planning Field Officers in increasing the long-term contraceptive usage in Parigi Moutong Regency, Central Sulawesi Province. This research was conducted with the aim of revealing new concepts about the role of the Field Officers. This research was conducted using qualitative approach. Data collection is done through interviews, observation, and document study. The results of the study illustrate that the role of the Field Officers in communicating Family Planning Programs to increase couples participation using long-term contraception has not yet materialized, because the quality of information delivered is insufficient.Local cultural factors also do not approve vasectomy because it is contrary to religious values. Based on the results of the study, the new findings raised were the capacity of the Field Officers, the social cultural and economic aspects of husband and wife, as well as the environment which greatly influenced the Field Officers' role in increasing community participation of long-term contraceptive usage in Parigi Moutong Regency.
\end{abstract}

Keywords: Communication Model, Family Planning Field Officers, Community Participation, Long-term Contraceptive Method

\section{Introduction}

The Republic of Indonesia is the world's fourth most populous country. The Major Three are the People's Republic of China, India and the United States of America (Andriani \& Wijaya, 2017). By regulating the population growth rate, the rate of economic growth that could improve people's wellbeing could be accomplished by suppressing the birth rate in each family (Aulia \& Mardiana, 2013). In the regional autonomyera, the Population, Family Planning and Family Development (PFPFD) program at the regency / municipal level was indeed a regional authority and even became a mandatory affair in accordance with the mandate of Government Regulation No. 38 of 2007 concerning the Division of Central and Regional Government Affairs. Therefore, the regions have the flexibility to develop the program to be more successful and beneficial. As organisations, government programs must have priorities to be accomplished (Pasinringi et al., 2020). However, despite being a regional authority, in its implementation, the direction of the PFPFD program must still refer to the policies of the National Family Planning Coordinating Board (NFPCB) as Non-Ministry Government Institutions nationally responsible for the success of the program. Thus, all 
regions are expected to synergize in achieving success in the PFPFD program in general (Widodo, 2010).

Law No. 52 of 2009 regarding the Population and Family Development explained that the National Family Planning Coordinating Board as a government institution in Indonesia has the task of controlling birth rate through the approach of four program pillars, namely Family Planning (widely known as KeluargaBerencana or $K B$ in Indonesia), Reproductive Health (widely known as Kesehatan Reproduksi or $K R$ in Indonesia), Family Welfare (widely known as Keluarga Sejahtera or $K S$ in Indonesia) and Family Empowerment Programs( widely known as Pemberdayaan Keluarga or $P K$ in Indonesia).

Family planning is the decision-making method between parents regarding the number of children they would like to have in their lifetime, together or separately, and the age interval between children. This ensures that there are equal rights for both sides of a marriage to settle about their future fertility (Getnet \& Getachew, 2019). The idea that family planning is just a sector for women is obsolete (Hardee et al., 2017). Modern contraceptive use in this study was described as any the following methods for delaying conception, i.e. female sterilization, intrauterine products, injectables (depo-provera), injections, tablets, condoms and emergency contraceptives (Damian et al., 2018). Whereas in order to accelerate fertility control through the use of contraception, national family planning programs in Indonesia are directed towards the use of the Long-Term Contraception Method (LTCM).

The most powerful method of contraception is the long-term contraceptive method (Ertiana \& Damayanti, 2018). Contraceptive use is one of the the most effective efforts in the Family Planning Program to control birth rate or suppress population growth. In its implementation, all contraceptives methods provided and offered to childbearing-age group to provide optimal benefits by minimizing side effects and complaints. Parigi Moutong Regency which have the largest population is one of the twelve Regencies and Cities in Central Sulawesi. The population of Parigi Moutong Regency currently reaches 413,588 people, consisting of 21,809 male inhabitants and 200,779 female inhabitants. The population growth rate per year in 2019 is 1.95 percent. Average population growth in 2019 for each district is 3.44 percent per year.Consequently, Parigi Moutong Regency also has a fairly high population density (Central Statistics Agency of Parigi Moutong Regency, 2018). The achievements of the longterm contraceptive participants throughout 2018 were only $13.22 \%$. The achievement of active family planning participants was dominated by non LTCM such as Injections, Pills, Condoms and other traditional methods (86.78\%) ( The Office of Women's Empowerment, Child Protection, Population Control and KB Kab. Parigi Moutong, 2018).

\section{Role, Pattern and Communication}

The term role is commonly referred to as a model, but the meaning is the same in which a system consisting of various components that are related to each other to achieve the goal of community education.Pattern is a form or model ora set of rules that is commonly used to make or to produce apart of something, especially if what is caused is enough to reach a type for the basic pattern that can be shown or seen (Littlejohn \& Foss, 2014).

Communication starts from ideas that exist in someone (Mufid, 2015). The idea is processed into a message and sent through certain media to other people as recipients. The recipient then tries to understood the message. By receiving a response from the recipient, the sender of the message can assess the effectiveness of the message and the extent to which the message is understood (Effendy, 2003).

Communication Pattern is a process designed to represent the reality of the elements covered and their continuity in order to facilitate systematic and logical thinking (Sukendar, 2017). 
Communication is one part of the relationship between humans, both individuals and groups, in everyday life (Effendy, 2015). Communication involves a number of people where a person expresses something to others.

\section{Methods}

This research style is descriptive qualitative (Mufti et al., 2020), due to the nature of the problem and the purpose of the study that examines the process and reveals the hidden meanings behind the real phenomenon and looks for answers to questions that emphasize experiences that are formed and given meaning by researchers (Sugiyono, 2013; Yusuf, 2017). A type of case study, literature reviews, and the latest data obtained from different social elements were used in this qualitative analysis (Rajindra et al., 2019). The authors used parameters and paradigms, including credibility, transferability, dependability, confirmability, to assess the validity of the data in this research (Zuada et al., 2019). In order to find and correctly understand details and functional trends in particular domains, some sort of visual knowledge model is becoming increasingly necessary (Gavrilova et al., 2019). Data processing consists of data condensing, interpreting data and drawing conclusions (Zulkifli et al., 2018). In order to further categorize them into obstacles or implementers, we then evaluated all the citations within each element/level of the frame-work (Hackett et al., 2020).

This research was conducted in Parigi Moutong Regency, Central Sulawesi Province, because we consideredthat this area is the most populous out of twelve regencies whereFamily Planning are dominated with non-LTCM such as injections and pills. The target location is four districts (Parigi, Ampibabo, Kasimbar \& Siniu) out of 23 districts in Parigi Moutong Regency, by considering the distance (far, medium and near).

Furthermore, data collection approaches have been carried out by field research (observation, interviews, documentation) (Kriyantono, 2009; Samad \& Kusuma, 2020). The informants are: the target group/recipients of the program, including male and female couple within childbearing-age groups that uses family planning (ten couple for each districts); those who have not used contraception; and the Implementator Group which includes District Coordinator of District Officers, Family Planning Field Officers, Village-level Family Planning Officers, as well as figures and staff of the Population Control and Family Planning Office. By adapting my technique to a previous social science analysis, I illustrate this argument (Suzuki, 2020).

\section{Results and Discussion}

Based on the results shows that the pattern of communication carried out by the Field Officers in Parigi Moutong Regency,especially in fourresearched districts (Parigi, Ampibabo, Kasimbar and Siniu District) has not succeeded in Increasing the Long-Term Contraception usage in Parigi Moutong Regency where it only achieved 19.18\%out of $68 \%$ target (The Department of Women's Empowerment, Child Protection, Population Control and Family Planning, Parigi Moutong Regency, 2020).

The low LTCM users in Parigi Moutong Regency, shows the ineffectiveness of communication patterns that have so far been used by the Field Officers. The total number of Field Officers is mere 23 officersin 23 subdistricts and 283 villagesa working area. There should be at least threeField Officers in each sub-district. In reality, there are just one officers assigned 8 to 10 villages. The officers is also insufficiently equipped for the mountaineous and hilly terrain (as per early observations of this research). 
The Field Officer's communication pattern is not only a communication phenomenon by itself, but also as a tool to explain and reduce communication phenomena. Therefore the Field Officers communication pattern illustrates ideal conditions are what is needed for communication. The Field Officers communication pattern in LTCM family planning services involves the role and function of communication as a message-gathering activity between Family Planning Field Officers as communicators and childbearing-age couples(CAC) as communicants involved in the servicereciprocally. Thus communication in this context can play a role in actualizing the message of service in ways that can encourage the achievement of the service goals

Communication activities carried out by Field Officers are not nearly the same. The communication pattern used, especially for LTCM, is a door-to-door and face to face communication pattern that does not use mass media and electronics. Overview of LTCM at the research location as samples are as follows:

\section{The Communication Pattern of Parigi District Field Officers}

Parigi District is one of the districts in Parigi Moutong Regency, which is located in coastal area, with the total area of $23.50 \mathrm{~km}^{2}$ consisted of 11 villages. Parigi District has a population of 29.826 in 2015 , increasing in 2016 to 31.271 , in $2017 \mathrm{~S}$ to 32.052 , in 2018 to 32.849 , and in 2019 increased to 33.798 inhabitants.

The yearly increase in population contributes to the level of population density. Population density in 2017 was $1.269,1.331$ in 2018, 1.364in 2019 crease in the number of households where in 2017 the number of households in Parigi District was 6.688, 6.728 in 2017, 6.915 in $2018,7.046$ in 2019 . On average, each family consisted of five people. The number of CAC in Parigi District is 5.459 with 3.638 of them are active family planning participants. Contraceptives used by CAC in Parigi District are: IUD (363),Tubectomy(431), Condom (7), Implant (357), Injection (1.353), Pills(1.119). The LTCM usage totaled at 1.151 or $25.24 \%$. Seeing LTCM usage that have not reached the specified target of $68 \%$,it can be said that the Communication Pattern that was built was ineffective.

The Field Officer of Parigi District, before carrying out the socialization, first visited the formal figures in the village. This is an indirect statement to request permission and approval to conduct an LTCM Family Planning socialization. Meetings with formal leaders and or village officials are usually held at the Village Office or Village Hall. The downside it that the meeting is not accompanied by a fixed monthly schedule. Because the next meeting depends on the situation and opportunity of the Field Officers.

The LTCM program is not yet well understood by the community. By the assumption that the contents of the message only revolved around the purpose and benefits of family planning, the socialization were incompletedas the community still doesn't understood the side effects. If misconceptions about side effects and long-term adverse effects continues, tackling systemic obstacles to access to contraception will be inadequate (Schrumpf et al., 2020). Religious approach is also not used in explaining LTCM, as a result CACs had false opinions about LTCM because the information was incomplete. The pattern of PLKB communication carried out in the field is face to face communication patterns, as well as door-to-door systems without using any media. This doorstep services is meant to improve customer satisfaction (Weidert et al., 2017). The lack of media such asprojectors, leaflets, television and radio as a supporting tool for socialization really dull the interest of the community.The target of the LTCM program socialization is the Childbearing Age Couples (CACs) who have used Family Planning program but have not used Long-Term Contraceptive Method. The family planning service phenomenon may also be inferred from 
errors in the recording (Wilonoyudho \& Prajanti, 2018). The Field Officers communication pattern in socializing LTCM did not have a good effect because the achievement of LTCM usage in Parigi District where at best only reached $30.71 \%$ out of $68 \%$ specified target.

\section{The Communication Pattern of Ampibabo District Field Officers}

Ampibabo District is one of the districts which is located in coastal area, with an area of $191.44 \mathrm{~km}^{2}$.Considering the distance from the Regency Capital, this district has 19 villages, with a population of 21.274 in 2015 , which increased to 21.880 in $2016,22.257$ in 2017 , 22.659 in 2018 , and 23.035 in 2019 . The average family has 5 family members. The number of CAC in Ampibabo District is totaling to 3.967 with 3.434 Family Planning participants. Contraception devices used by CACs in Ampibabo District are: IUD (388), Tubectomy (69), Condom (31), Implant (631), Injection (750), Pills (561). The LTCM usage are rated at $25,47 \%$. The LTCM usage in AmpibaboDistrict has not yet reached the target set by the Parigi Moutong Government, which is $68 \%$.

Field Officer of Ampibabo District, prior to conducting the socialization, did not involve formal or informal figures in the village. The meeting was not continuous and was not well scheduled.It was happened because the Field Officers did not have a fixed meeting schedule. The LTCM program is not yet well understood by the community. By the assumption that the contents of the message only revolved around the purpose and benefits of family planning, the socialization were incompletedas the community still doesn't understood the side effects.

Religious approach is also not used in explaining LTCM, as a result CACs had false opinions about LTCM because the information was incomplete.The carried out communication pattern only uses face to face communication patterns, as well as door-todoor systems without using any supporting media or tools for socializations. The target of the LTCM program socialization is the Childbearing Age Couples (CACs) who have utilizedFamily Planning but have not used LTCM.The Field Officers communication pattern in socializing LTCM program did not have a good effect because the LTCM usage did not reach the specified target of $68 \%$.

\section{The Communication Pattern of Kasimbar District Field Officers}

Kasimbar District is located in the mountain range with an area of $280.78 \mathrm{~km}^{2}$, consisted of 18 villages with a population reaching 21.569 in 2016, increasing to 22.232 in $2017,22.637$ in $2018,23.068$ in 2019 and 23.474 in 2020.

The yearly increase of population contributes to the level of population density. The population density in 2016 was 77, increased to 79 in 2017, 80 in 2018, 82in 2019 and 84in 2020 The density was definitely closely related to the increase in the number of households across the years.In 2016, the number of households in Kasimbar was 4.887.This number increased in 2017 to 4.985 and in 2018 to 5.125.in last two years, it increased yet again to 5.221 in 2019 as well as to 5.314in 2020.

Each family has 4 family members on average. The number of CACs in Kasimbar totaling to 4.111 with 2.873 of them are active Family Planning Participants. Contraception devices used by CAC in Kasimbar are: IUD (107), Tubectomy(34), Implants (169), Injection (1.213), andPills (1.258). The LTCM usage reach $10.96 \%$ compared to the $89.04 \%$ of non LTCM usage. The LTCM usage at Kasimbar is very low compared to Parigi and Ampibabo.So it can be said that the Communication Patterns that were built were ineffective. 
The Field Officer of Kasimbar did not involve formal or non-formal village figures. The meetings and socializations are not continuous and not well scheduled. It happened because the Field Officer did not have a fixed schedule. The lack of religious approach in explaining LTCM and incomplete information is making CACsgrow wary and had false opinions about LTCM.By the assumption that the contents of the message only revolved around the purpose and benefits of family planning, the socialization were incompletedas the community still doesn't understood the side effects.

The pattern also only uses face to face communication patterns, as well as door-to-door systems without using any supporting media or tools for socializations. The target of the LTCM program socialization is the Childbearing Age Couples (CACs) who have utilizedFamily Planning but have not used LTCM.The Field Officers communication pattern in socializing LTCM program did not have a good effect because the LTCM usage did not reach the specified target of $68 \%$.

\section{The Communication Pattern of Siniu District Field Officers}

Siniu Districtis located in coastal area of $118.96 \mathrm{~km}^{2}$ which consisted of 9 villages with a population of 8.749in 2016 .The population increase to 8.888 in $2017,8.932$ in 2018 ,9.139in 2019, and 9.189in 2020.

The population density of Siniu is inconsistent. The population density in 2016 was 74, increased to 75in 2017, become stagnant in 2018 at 75, increased to 77 in 2019 and become stagnant yet again at 77in 2020 .Thus, even though the population density was closely related to the increase in the number of population households across the year, the population density at Siniu is inconsistent troughout the years. The number of households in Siniu was 2.008 in 2016 .In 2017, it increased to 2.073. The number of household continue to increase throughout following years, reaching to 2.131in 2018, 2.359 in 2019 but it decreased to 2.210in 2020.

On average each family has 4 people of family members. The number of CACs in Siniuis totaling to 1.831 with 1.450 of them are active Family Planning Participants. The Contraception device used in Siniu District are: IUD (36), Tubectomy (5), Vasectomy (41), Condom (85), Implants (145), Injections (577), and Pills (553).The LTCM usage at Siniu reaches $15.65 \%$. The usage compared to Parigi District is relatively low.

The Field Officer of Siniuin carrying out the socialization did not involve formal or informal figures in the village. The meeting was also not continuous and was not well scheduled. It happened because the Field Officer did not have a monthly meeting schedule and the meetings and socializations are held sporadically. This causes the LTCM program to be not well understood by the community. Religious approach is also not used in explainingLTCM, as a result CACs had false opinions about LTCM because the information was incomplete.

The Field Officers only uses face to face communication patterns, as well as door-to-door systems without using any media. The lack of media such asprojectors, leaflets, television and radio as a supporting tool for socialization really dull the interest of the community.The target of the LTCM program socialization is the Childbearing Age Couples (CACs) who have used Family Planning program but have not used Long-Term Contraceptive Method.The socialization did not have good effects because the usage numbers only reached $15.65 \%$ out of $68 \%$ of targeted usage. But the implemented pattern is better compared to Kasimbar's $10.96 \%$ of LTCM usage.

\section{The Difficulties in Communicating the LTCM Family Planning Program}


The language difference is considered a semantic disorder. Semantic interference is a disorder associated with a broken communication message that result in different understanding and terms between communicators and communicants. Parigi Moutong Regency havevarious kinds of Kaili languages (KailiLedo, KailiRai, Kaili Tara andKailiUnde for example). Thus, the Field Officers are facing difficulty to determine which language to use and what was conveyed sometimes misunderstood or misinterpreted.

Aside from the language differences, there are psychological barriers related to prejudice. A lot of CACs are generally did not trust the efficacy of the Long-Term Contraceptive Method of Family Planning. During the socialization, a lot of CACs also shown disinterest towards the presentations. The low level of education and economy of CACs also have a part in this.

The Field Officers also haven't accurately presented the LTCM program in meetings or socializations. The lack of continuous meetings or socialization and supporting medias also cripples the information delivery and dulls the CACs interest on the socialization and education process of LTCM program. The lack of religious approach and religious leader involvement also sparks CAC's biased opinion and indecisiveness. It also worth to be noted that most Field Officers have low capacity in building a conducive communication environment with CACs, figureheads and religious or community leaders. In a hierarchical system of priorities, future differences with results of intentions at various levels are controlled, and processes are continually learned and modified by measurement and assessment mechanisms (Williams et al., 2020). Where the perception of persons is seen as coconstructed through continual encounters between the intellectual, social and physiological state (Baenziger et al., 2020).

\section{Conclusion}

Based on the results of the research and discussion it can be concluded that the pattern of communication carried out by the Family Planning Field Officers in Parigi Moutong Regency, especially in fourresearched Districts (Parigi, Ampibabo, Kasimbar and Siniu) has not succeeded in increasing Childbearing Age Couples in Long-Term Contraception usage.The research findings show that the Field Officer's Communication Pattern had similarities both from the communicator aspect where the Field Officers did not fully explain the side effects of each Family Planning and LTCM program; did not use any supporting communicationmedia; and carried out face to face only without the use of assistive devices. As a result, it did not have an effect on improving LTCM usage. It also shows that the four mentioned districts have not reached the $68 \%$ target set by the Parigi Moutong Government.

\section{References}

Andriani Lubis, L., \& Wijaya, H. (2017). Communication Strategy on Family Planning Campaign by the Field Officer for Family Planning Campaign in North Sumatera. International Journal of Innovation and Economic Development, 3(4), 53-59. https://doi.org/10.18775/ijied.1849-7551-7020.2015.34.2005

Aulia Dewi Listiyana \& Mardiana, G. N. P. (2013). The Effect of Physical and Socio-cultural Environments on the Access of Family Planning Service in Poor Couples of Reproductive Age in Sabu Raijua Regency. Jurnal Kesehatan Masyarakat, 9(1), 3743.

Badan Pusat Statistik Kabupaten Parigi Moutong. (2018). Kabupaten Parigi Moutong Dalam Angka.

Baenziger, J., Hetherington, K., Wakefield, C. E., Carlson, L., McGill, B. C., Cohn, R. J., Michel, G., \& Sansom-Daly, U. M. (2020). Understanding parents' communication 
experiences in childhood cancer: a qualitative exploration and model for future research. Supportive Care in Cancer, 28(9), 4467-4476. https://doi.org/10.1007/s00520-019-05270-6

Damian, D. J., George, J. M., Martin, E., Temba, B., \& Msuya, S. E. (2018). Prevalence and factors influencing modern contraceptive use among HIV-positive women in Kilimanjaro region, northern Tanzania. Contraception and Reproductive Medicine, 3(1), 1-9. https://doi.org/10.1186/s40834-018-0060-2

Dinas Pemberdayaan perempuan perlindungan anak Pengendalian Penduduk dan KB Kab. Parigi Moutong. (2018). Data Penggunaan KB Jangka Panjang.

Effendy, O. U. (2003). Ilmu, Teori dan Filsafat Komunikasi. PT. Citra Aditya Bakti.

Effendy, O. U. (2015). Dinamika Komunikasi. Remaja Rosdakarya.

Ertiana, D., \& Damayanti, Y. (2018). The Difference of Productive Couple Age in Using Long- Term Contraception Method in Family Planning and in Non - Family Planning Village, in Public Health Center of Adan - Adan Kediri Regency. The 2nd Joint International Conferences, 1, 239-249.

Gavrilova, T., Kudryavtsev, D., \& Grinberg, E. (2019). Aesthetic knowledge diagrams: Bridging understanding and communication. Knowledge Management and Organizational Learning, 7, 97-117. https://doi.org/10.1007/978-3-030-10922-6_6

Getnet, D., \& Getachew, H. (2019). A Study on the Practice of Health Communication Strategies on Family Planning At East Gojjam Zone, Amhara Region, Ethiopia. Www.Ijbmm.Com International Journal of Business Marketing and Management, 4(September), 2456-4559. www.ijbmm.com

Hackett, K., Huber-Krum, S., Francis, J. M., Senderowicz, L., Pearson, E., Siril, H., Ulenga, N., \& Shah, I. (2020). Evaluating the implementation of an intervention to improve postpartum contraception in Tanzania: A qualitative study of provider and client perspectives. Global Health Science and Practice, 8(2), 270-289. https://doi.org/10.9745/GHSP-D-19-00365

Hardee, K., Croce-Galis, M., \& Gay, J. (2017). Are men well served by family planning programs? Reproductive Health, 14(1), 1-12. https://doi.org/10.1186/s12978-0170278-5

Kriyantono, R. (2009). Teknik Praktis Riset Komunikasi. Kencana Perdana Media Group.

Littlejohn, S. W., \& Foss, K. A. (2014). Teori Komunikasi Theories of. Human Communication (9th ed.). Salemba Humanika.

Mufid, M. (2015). Etika dan Filsafat Komunikasi. Kencana.

Mufti, M. I., Kurnia, I., Karim, I., \& Samad, M. A. (2020). Evaluation on Community Empowerment Policy after Conflict Resolution ( A Study of Sub District Development Program in Poso District ). International Journal of Multicultural and Multireligious Understanding, 7(8), 16-25. https://doi.org/10.18415/ijmmu.v7i8.1792

Pasinringi, A., Alamsyah, M. N., \& Samad, M. A. (2020). Measuring the Level of Discipline of Bureaucrats in Palu City. International Journal of Multicultural and Multireligious Understanding, 7(10), 79. https://doi.org/10.18415/ijmmu.v7i10.2011

Rajindra, R., Suardi, I., \& Sabara, Z. (2019). Diversity, Resilience , and Tragedy: Three 
Disasters in Palu of Indonesia. International Journal of Innovation, Creativity and Change, 5(2), 1592-1607.

Samad, M. A., \& Kusuma, E. Z. (2020). Apparatus Resources Development in The Regional Agency of the Palu City. International Journal of Multicultural and Multireligious Understanding, 7(7), 233-237.

Schrumpf, L. A., Stephens, M. J., Nsarko, N. E., Akosah, E., Baumgartner, J. N., OhemengDapaah, S., \& Watt, M. H. (2020). Side effect concerns and their impact on women's uptake of modern family planning methods in rural Ghana: A mixed methods study. BMC Women's Health, 20(1), 1-8. https://doi.org/10.1186/s12905020-0885-0

Sugiyono. (2013). Metode Penelitian Kuantitatif, Kualitatif dan $R \& D$. Alfabeta.

Sukendar, M. U. (2017). Psikologi Komunikasi: Teori dan Praktek. Deepublish.

Suzuki, A. (2020). Presenting the probabilities of different effect sizes: Towards a better understanding and communication of statistical uncertainty. ArXiv.

Weidert, K., Gessessew, A., Bell, S., Godefay, H., \& Prata, N. (2017). Community health workers as social marketers of injectable contraceptives: A case study from Ethiopia. Global Health Science and Practice, 5(1), 44-56. https://doi.org/10.9745/GHSP-D16-00344

Widodo. (2010). Analisis Kebijakan Publik: Konsep dan Aplikasi Analisis Proses Kebijakan Publik. Bayu Media.

Williams, J. H. G., Huggins, C. F., Zupan, B., Willis, M., Van Rheenen, T. E., Sato, W., Palermo, R., Ortner, C., Krippl, M., Kret, M., Dickson, J. M., Li, C. shan R., \& Lowe, L. (2020). A sensorimotor control framework for understanding emotional communication and regulation. Neuroscience and Biobehavioral Reviews, 112(December 2018), 503-518. https://doi.org/10.1016/j.neubiorev.2020.02.014

Wilonoyudho, S., \& Prajanti, S. D. W. (2018). Anomalies in Family Planning in Central Java, Indonesia. KOMUNITAS: International Journal of Indonesian Society and Culture, 10(1), 86-91. https://doi.org/10.15294/komunitas.v10i1.9634

Yusuf, M. (2017). Metode Penelitian: Kuantitatif dan Penelitian Gabungan. Kencana.

Zuada, L. H., Samad, M. A., \& Aisyah, N. (2019). Journal of Public Administration and Government Kajian Tingkat Kepercayaan Publik Terhadap Dewan Perwakilan Daerah Provinsi Sulawesi Tenggara Study of the Level of Public Trust in the Regional Representatives Council Southeast Sulawesi Province. Journal of Public Administration and Government, 1(April), 9-22.

Zulkifli, Z., Suasa, S., Mukarramah, M., Daswati, D., \& Samad, M. A. (2018). Village Funds Supervision by the Village Consultative Body (BPD) in Batumatoru Village, Lariang District, Pasangkayu Regency. PINISI Discretion Review, 1(2), 109. https://doi.org/10.26858/pdr.v1i2.13161 